\title{
HT update: spotlight on estradiol/norethindrone acetate combination therapy
}

\section{Colleen L Casey \\ Christine A Murray}

University of Vermont, Department of Obstetrics and Gynecology, Division of Reproductive Endocrinology and Infertility, Burlington, VT, USA
Correspondence: Colleen L Casey University of Vermont, Department of Obstetrics and Gynecology, Division of Reproductive Endocrinology and Infertility, I I Colchester Ave, Smith 422, Burlington, VT 0540I, USA

$\mathrm{Tel}+\mathrm{I} 8028473450$

Fax +l 8028479243

Email colleen.casey@vtmednet.org

\begin{abstract}
The goal of postmenopausal hormone therapy is to alleviate the symptoms that are associated with the loss of estrogen. Many formulations of estrogen and progestin are available, depending on the needs and circumstances of each individual woman. For postmenopausal women, the choice of whether or not to begin therapy requires knowledge of the risks and benefits of estrogen and/or progestin replacement. The purpose of this review is to describe the risks and benefits of hormonal therapy, focusing on estradiol/norethindrone acetate combination therapy.
\end{abstract}

Keywords: postmenopausal hormone therapy, norethindrone acetate, estradiol

The first reported use of hormonal therapy to alleviate hot flashes was reported in 1897 (Fosbery et al 1897). This was accomplished by administering ovarian extract to postmenopausal women. Synthetic estrogens were made available in the 1930s in the form of stilbestrol and ethinyl estradiol. Estradiol was isolated in 1936, but unfortunately, it took 4 tonnes of sows' ovaries to isolate $12 \mathrm{mg}$ of hormone. Isolating progesterone proved equally challenging. In 1934 crystalline progesterone was isolated from the corpora lutea of 50,000 pigs by Drs. George W Corner and Willard Myron Allen (Speroff et al 2005).

Hormone replacement therapy became common in the United States and Europe in the 1960s, mainly in the form of ethinyl estradiol. The decline of use in the 1970s was attributed to the increased risk of endometrial cancer secondary to unopposed estrogen. Progestins were added in the 1980s, which decreased the incidence of endometrial cancer and subsequently increased postmenopausal hormonal therapy use (Stahlberg et al 2003). In the 1990s, it was well established that postmenopausal estrogen therapy prevented osteoporosis, and observational studies suggested that estrogen may prevent the development of cardiovascular and Alzheimer's disease. By the late $1990 \mathrm{~s}, 25 \%$ of all US women over the age of 40 used hormonal therapy (Brett et al 2003). In 2002, the Heart and Estrogen/Progestin Replacement Study (HERS II), a randomized controlled clinical trial, reported no cardiovascular benefit to women with established heart disease while taking combined estrogen and progestin therapy (Grady et al 2002). Following this, the randomized controlled clinical trial Women's Health Initiative (WHI) reported a higher incidence of both breast cancer and cardiovascular events in women taking combined conjugated estrogen and medroxyprogesterone therapy (Rossouw et al 2002). The second arm of the WHI, which evaluated unopposed estrogen for women with previous hysterectomies, was discontinued in 2004 secondary to observance of an increased risk of stroke and lack of protection against cardiovascular disease. The Food and Drug Administration (FDA) responded to these studies by changing the labeling for postmenopausal hormone therapy, limiting 
the indications for therapy to reducing the occurrence of menopausal symptoms and osteoporosis (Hing and Brett 2006). Over the next 2 years, the number of women 40 and older requesting hormone therapy declined significantly, as the number of visits resulting in a prescription for hormone therapy prescribed decreased from 26.5 million in 2001 to 16.9 million in 2003 (Hing and Brett 2006). Recently, a task force has been established by Charles Hammond, MD, of the American College of Obstetricians and Gynecologists (ACOG) to evaluate the risks and benefits of hormone therapy (Table 1) (Executive Summary 2004).

The combination of ethinyl estradiol and norethindrone acetate has been used for both oral contraception and postmenopausal hormonal therapy. In general, these hormones mimic the natural hormones estrogen and progesterone, respectively. These steroids bind to their receptor, activating hormone response elements and gene transcription; this subsequently activates hormone response proteins that influence cell function and differentiation (Clark et al 2002).

\section{Pharmacology}

The source of estrogen in cycling women is the ovarian follicle, which secretes 70-500 $\mu \mathrm{g}$ depending on the phase of the cycle. In postmenopausal women, androstendione, a hormone produced in the adrenal gland, is converted peripherally into estrone and can be conjugated to form estrone sulfate. These estrogens are biologically active and are similar to ethinyl estradiol.

Table I Benefits/risks of hormone therapy: 2004 Executive Summary (ACOG)

\begin{tabular}{|c|c|c|}
\hline Benefits & Comment & $\begin{array}{l}\text { Relative risk: based on conjugated } \\
\text { estrogen (CEE)/medroxyprogesterone } \\
\text { (MPA) vs placebo of WHI }\end{array}$ \\
\hline Vasomotor symptoms & Estrogens most effective treatment & $\mathrm{N} / \mathrm{A}$ \\
\hline Sexual dysfunction & $\begin{array}{l}\text { Estrogens effective in relieving atrophy } \\
\text { and dyspareunia }\end{array}$ & $\mathrm{N} / \mathrm{A}$ \\
\hline Skin & $\begin{array}{l}\text { Increased collagen content and wrinkle } \\
\text { reduction (non-sun-exposed areas }\end{array}$ & $\mathrm{N} / \mathrm{A}$ \\
\hline Genitourinary tract & Reduces atrophic vaginitis & $N / A$ \\
\hline Depression & Estrogen may have antidepressant effects & $N / A$ \\
\hline Colorectal cancer & & $0.56(0.38-0.81)$ \\
\hline Osteoporosis & $\begin{array}{l}\text { Estrogens are effective antiresorptive agents } \\
\text { and improves bone density }\end{array}$ & $0.76(0.69-0.83)^{\mathrm{a}}$ \\
\hline \multicolumn{3}{|l|}{ Risks } \\
\hline Breast cancer & $\begin{array}{l}20 \text { per } 10,000 \text { risk over } 5 \text { years if use combined } \\
\text { estrogen/progestin therapy, no increased risk } \\
\text { with estrogen therapy alone }\end{array}$ & $1.24(1.01-1.54)$ \\
\hline \multirow[t]{8}{*}{ Coronary heart disease } & Age: & \\
\hline & $50-59$ & $1.27(0.75-2.20)$ \\
\hline & $60-69$ & $1.05(0.70-1.80)$ \\
\hline & 70-79 & $1.44(0.90-2.00)$ \\
\hline & Years since menopause: & \\
\hline & $<10$ & $0.89(0.50-1.50)$ \\
\hline & $10-19$ & $1.22(0.80-1.80)$ \\
\hline & $20+$ & $1.71(1.20-2.50)$ \\
\hline \multirow[t]{2}{*}{ Thromboembolic disease } & 2-fold greater risk with increased risk of $\mathrm{PE}$, & DVT: $1.95(1.43-2.67)$ \\
\hline & highest risk during first year of use & PE: $2.13(1.45-3.11)$ \\
\hline Stroke & Randomized controlled trials show increased risk & $1.31(1.02-1.68)$ \\
\hline Cognition & $\begin{array}{l}\text { Women's Health Initiative Memory Study } \\
\text { (WHIMS) - sbset of WHI, found increased } \\
\text { risk of probable dementia }\end{array}$ & $2.05(1.21-3.48)$ \\
\hline \multicolumn{3}{|l|}{ Neutral } \\
\hline $\begin{array}{l}\text { Weight changes/insulin } \\
\text { resistance }\end{array}$ & $\begin{array}{l}\text { No changes, glycemic control in type } 2 \text { diabetes } \\
\text { unchanged by hormonal therapy }\end{array}$ & $\mathrm{N} / \mathrm{A}$ \\
\hline Osteoarthritis & & $\mathrm{N} / \mathrm{A}$ \\
\hline \multirow[t]{2}{*}{ Ovarian and endometrial cancer } & & Ovarian: I.58 (0.77-3.24) \\
\hline & & Endometrial: 0.8I (0.48-I.36) \\
\hline
\end{tabular}

${ }^{a}$ number of total fractures, including hip, vertebral and lower arm/wrist.

Abbreviations: PE, pulmonary embolism; DVT, deep vein thrombosis. 
Progesterone opposes estrogens by decreasing estrogen receptors. In the endometrium, progesterone binds to its receptor, dimerizes, and binds to progesterone response elements. This, in turn, induces gene transcription thus activating the secretory phase.

Estradiol is the main estrogen that is secreted by the ovaries, and is the most potent. It is inactive if administered orally. In 1938 it was discovered that adding an ethinyl group at the 17 position of the steroid molecule made the hormone orally active. Equally important was the discovery of norethindrone in 1951, which is derived from the androgen ethisterone. Norethindrone is formed by removing the 19-carbon from the ethisterone, thereby changing the effect from an androgen to a progestin (Speroff and Fritz 2005).

Ninety-eight percent of estradiol and norethindrone components circulate bound to sex hormone binding globulin and albumin. Approximately $2 \%$ of estradiol and norethindrone circulates unbound in its free form. Peak plasma estrogen levels are reached within 5-8 hours of oral administration. After oral administration, norethindrone acetate is quickly deacylated to norethindrone and reaches a peak plasma level within $0.5-1.5$ hours. Steady state levels of estradiol, estrone, and norethindrone are reached after 2 weeks of daily administration. The half-life of estradiol after a single dose is $12-14$ hours, and the terminal half-life of norethindrone sulfate is $8-11$ hours. Both norethindrone and estradiol are subject to first past metabolism, and retain $65 \%$ and $55 \%$ of their bioavailability, respectively.

When taken orally, estradiol is metabolized to mostly estrone sulfate. In the liver, estradiol is converted to other active metabolites, including estrone and estriol. Estrogens undergo sulfate and glucorunide conjugation in the liver and are recirculated in these forms. Hydrolysis of estrogen occurs in the intestine with subsequent reabsorption. Estradiol, estrone, and estriol are all excreted into the urinary system.

The norethindrone metabolites $5 \alpha$-dihydro-norethindrone and tetrahydro-norethindrone undergo sulfate or gluconate conjugation and are excreted into the urine.

\section{Current preparations of combination estradiol (E2)/ norethindrone acetate (NETA)}

Activella ${ }^{\circledR}$ (Novo Nordisk Inc., Princeton, NJ, USA) contains a combination of estradiol and norethindrone acetate available in tablet form. It is available in two doses $(1 \mathrm{mg} / 0.5 \mathrm{mg}$, $0.5 \mathrm{mg} / 0.1 \mathrm{mg}$ ) and is taken once daily.
Combipatch $^{\circledR}$ (Novartis, Miami, FL, USA) is an adhesive patch that contains both estradiol and norethindrone acetate and provides a continuous release of both hormones. It is available in two doses, either $0.05 \mathrm{mg} / 0.14 \mathrm{mg}$ or $0.05 / 0.25 \mathrm{mg}$ per day.

femhrt $^{\circledR}$ (Duramed Pharmaceuticals, Pomona, NY, USA) is an oral hormone alternative that contains norethindrone acetate and ethinyl estradiol. It is available in two doses $(0.5 \mathrm{mg} / 2.5 \mu \mathrm{g}$ or $1 \mathrm{mg} / 5 \mu \mathrm{g})$.

\section{Clinical indications}

The indications for postmenopausal E2/NETA hormone therapy include treatment of severe vasomotor symptoms and prevention of postmenopausal osteoporosis. Current guidelines by the FDA recommend therapy at the lowest effective dose and shortest duration as possible.

\section{Vasomotor symptoms}

A 12-week randomized placebo-controlled trial showed that E2/NETA significantly decreased hot flushes at weeks 4 and 12. At the conclusion of this study, $85 \%$ of women receiving E2/0.5 mg NETA and $71 \%$ of the women receiving E2/0.25 mg reported adequate relief of moderate to severe hot flushes (Bauerug et al 1998).

Gambacciani et al investigated the effect of daily E2/ NETA and its effect on quality of life in early postmenopausal women and found a significant decrease in severity of hot flushes, anxiety/fear, depressed mood and sleep problems compared to placebo (Gambacciani et al 2003).

Adler at al investigated both patient and physician satisfaction with the transdermal $17 \beta$-estradiol plus norethindrone acetate therapy and found a significant reduction in the mean daily number of moderate-to-severe hot flashes experienced by women after 12 weeks of use from 4.1 at week 1 to 0.6 at week $12(\mathrm{p}<0.0001)$. They also found that headache severity, insomnia, and vaginal irritation/dryness improved significantly by week 6 and were maintained at week 12 . After 12 weeks of therapy, $92.4 \%$ of the subjects and $97.3 \%$ of the physicians reported that they were 'satisfied' or 'very satisfied' with the transdermal hormone delivery system (Adler et al 2005).

A randomized, double-blind multicenter study evaluated 625 postmenopausal women with 3 doses of combined transdermal E2/NETA compared to unopposed E2. Intensity of hot flashes was graded as 0 (none), 1 (mild), 2 (moderate) and 3 (severe) and prior to and after 12 months of treatment (Table 2. Hot flushes were decreased in all groups (Archer et al 1999). 
Table 2 Intensity of hot flushes after 12 months of hormone therapy

\begin{tabular}{lllll}
\hline $\begin{array}{l}\text { Intensity of } \\
\text { hot flushes }\end{array}$ & E2 $50 \mu \mathrm{g}$ & $\begin{array}{l}\text { E2 } 50 \mu \mathrm{g} / \\
\text { NETA }\end{array}$ & $\begin{array}{l}\text { E2 } 50 \mu \mathrm{g} / \\
\text { NETA }\end{array}$ & $\begin{array}{l}\text { E2 } 50 \mu \mathrm{g} / \\
\text { NETA }\end{array}$ \\
& & $\mathbf{1 4 0} \boldsymbol{\mu g}$ & $\mathbf{2 0 0} \boldsymbol{\mu g}$ & $\mathbf{4 0 0 \mu \mathrm { g }}$ \\
\hline Baseline & $\mathrm{I} .32$ & 1.32 & 1.42 & 1.54 \\
Endpoint & 0.18 & 0.35 & 0.19 & 0.14 \\
\hline
\end{tabular}

\section{Bone mineral density}

Bone resorption is the first process to occur after menopause and the secondary to estrogen deficiency. In the 1980s, studies linked E2/NETA to increased forearm bone mass (Christiansen et al 1980, 1981). It is likely that both E2 and NETA contribute positively to increased bone mass in postmenopausal women. A 2-year randomized, doubleblind, placebo-controlled trial looked at varying doses of E2/NETA on postmenopausal women and found that bone mineral density increased by $4.8 \%$ and $5.4 \%$ with higher doses of NETA ( $0.5 \mathrm{mg}$ vs $1.0 \mathrm{mg}$ daily) along with $1 \mathrm{mg}$ E2 (McClung 1998). Roux et al performed a 2-year randomized comparing tibolone and E2/NETA for preventing bone loss in postmenopausal women and found that each medication was effective. E2/NETA showed an increase in lumbar spine bone mineral density of $6.8 \% \pm 4.5 \%$ after 2 years of therapy (Roux et al 2002). Popp et al found similar results when treating postmenopausal women with E2/NETA, with an increase in lumbar spine of $3.8 \% \pm 0.6 \%$ (Popp et al 2006). Similar results have been found by other investigators (Table 3) (Arabi et al 2003). E2/NETA in combination is beneficial for women with established osteoporosis. Women with previous osteoporotic fractures participated in a double - blind study of $2 \mathrm{mg}$ E2/1 mg NETA or placebo. After 12 months of therapy, lumbar spine density had increased by $8 \%-10 \%$ and total skeleton and distal forearm increased by 3\%-5\% compared with placebo (Christiansen et al 1990).

Ravn et al compared the effects of alendronate, a bisphosphanate to sequential E2/NETA ( $2 \mathrm{mg}$ E2 daily + $1 \mathrm{mg}$ NETA for 10 days monthly). After 2 years of treatment, HT led to a significantly greater increase in bone mineral density in the spine, hip and total body. Table 4 summarizes the results (Ravn et al 1999).

\section{Risks}

\section{Endometrial hyperplasia}

Several studies have evaluated the protective effects of NETA on estrogen-induced hyperplasia in postmenopausal women.
A randomized controlled clinical trial was performed comparing placebo, unopposed estrogen and combined E2/ NETA with different doses of NETA. A significant decrease in endometrial hyperplasia was found in patients receiving combination E2/NETA therapy compared to estrogen only treatment (Table 5) (Kurman et al 2000).

A blinded, randomized, controlled trial compared 2 combinations of hormone therapy on occurrence of postmenopausal uterine bleeding and endometrial histology. The investigators randomized 945 women for 12 months to E2/NETA(varying doses mg NETA/ $\mu g$ E2: 0/5, 0.25/5, 1/5, $0 / 10,0.5 / 10,1 / 10)$ or to $0.625 \mathrm{mg}$ conjugated equine estrogens (CEE)/2.5 mg medroxyprogesterone acetate (MPA). Endometrial sampling was performed at 0,6 , and 12 months of therapy. The investigators found that E2/NETA therapy had significantly higher percentage of atrophic endometrium at 12 months compared with the CEE/MPA group (73\% vs $32 \%$, respectively) (Portman et al 2003). Similar results have been obtained comparing continuous NETA vs MPA for contraceptive therapy and subsequent risk of developing endometrial cancer $(\mathrm{OR}=1.07 ; 95 \% \mathrm{CI} 0.86,1.33 \mathrm{vs} \mathrm{OR}=0.85$ 95\% CI 0.73, 0.98) (Weiderpass et al 1999).

Wells et al (2002) looked at the endometrial effects after long-term E2/NETA therapy. British women taking $2 \mathrm{mg}$ E2/1 mg NETA were followed for 5 years at 31 clinics. Endometrial biopsies were obtained at 0, 9, and 24-36 months of treatment. None of the 398 women completing the study had evidence of endometrial hyperplasia or malignancy. Interestingly, women with a previous diagnosis of complex hyperplasia prior to the initiation of therapy had normal endometrial biopsies at the end of treatment.

A randomized, double blind, multicenter study evaluated 625 postmenopausal women with 3 doses of combined E2 and NETA compared to unopposed E2. Women were assigned to E2 $50 \mu \mathrm{g}$ per day or transdermal E2/NETA with $50 \mu \mathrm{g}$ E2 and 140, 250, or $400 \mu \mathrm{g}$ of NETA. Endometrial biopsies were performed 12 months after treatment. Endometrial hyperplasia was significantly lower in the E2/NETA groups (Table 6) (Archer et al 1999).

Table 3 Changes in bone mineral density after 2 years of E2/NETA therapy

\begin{tabular}{lllll}
\hline & $\begin{array}{l}\text { Total } \\
\text { body }\end{array}$ & $\begin{array}{l}\text { Lumbar } \\
\text { spine }\end{array}$ & $\begin{array}{l}\text { Total } \\
\text { femur }\end{array}$ & $\begin{array}{l}\text { Femoral } \\
\text { neck }\end{array}$ \\
\hline $\begin{array}{l}\text { Percentage } \\
\text { change }\end{array}$ & $+2.9( \pm 2.4)$ & $+6.9( \pm 4.2)$ & $+3.4( \pm 3.6)$ & $+4.0( \pm 3.4)$ \\
\hline
\end{tabular}


Table 4 Changes in bone mineral density with E2/NETA vs alendronate

\begin{tabular}{lllll}
\hline & Spine & Hip & Forearm & Total body \\
\hline $2 \mathrm{mg}$ E2/I mg & $+5.14 \%$ & $+3.21 \%$ & $+0.54 \%$ & $+2.59 \%$ \\
NETA & $\mathrm{P}<0.0 \mathrm{I}$ & $\mathrm{P}<0.00 \mathrm{I}$ & & $\mathrm{P}<0.00 \mathrm{I}$ \\
Alendronate & $+3.34 \%$ & $+1.60 \%$ & $-\mathrm{I} .14 \%$ & $0.64 \%$ \\
\hline
\end{tabular}

\section{Other physiologic effects Memory and cognition}

Longitudinal data from the Nurses Health Study and randomized clinical trial data from the Women's Health Initiative have failed to show cognitive benefits with the use of postmenopausal hormonal therapy. Recently, Smith et al randomized patients to $5 \mu \mathrm{g}$ E2/1 $\mathrm{mg}$ NETA or placebo and performed functional magnetic resonance imaging study. They found that hormonal therapy was associated with significantly higher activation in the prefrontal cortex, an area of the brain critical in primary visual working memory, specifically monitoring, organization and planning (Smith et al 2006).

\section{Cardiovascular disease}

Cardiovascular disease is the leading cause of death among postmenopausal women, and unlike men, the death rate has remained relatively constant over the past 20 years. No randomized clinical trials have shown a benefit of postmenopausal hormone therapy for coronary heart disease as compared to placebo (ACOG Coronary Heart Disease Supplement 2004). Although most of these studies used different preparations of estrogen and progestin, one trial did use combination E2/NETA.

The Papworth HRT Atherosclerosis Study (PHASE) evaluated 255 postmenopausal women with coronary artery disease who were randomly assigned to transdermal administration of $17 \beta-E 2$ if previous hysterectomy, $17 \beta-E 2$ plus NETA if no previous hysterectomy or placebo. The primary endpoint included cardiac death, myocardial infarction, or hospital admission for unstable angina. There were 53 primary endpoint events in the hormone group and 37 events in the placebo group (HR 1.29, 95\% CI 0.84-1.95) (Clark et al 2002). More recently, it has been shown that coronary-artery calcification scores are lower among women receiving estrogen as compared to placebo (83.1 vs 123.1, respectively, $\mathrm{p}<0.02$ ). The long term cardiovascular benefit of estrogen on cardiovascular disease due to decreased arterial calcification has yet to be determined (Manson et al 2007). At this time, hormone replacement therapy cannot be recommended for primary or secondary prevention of cardiovascular disease.

\section{Venous thromboembolic disease}

Venous thromboembolic disease includes thrombosis of the retinal veins, deep veins of the legs, upper extremities or pulmonary arteries (ACOG Venous Thromboembolic Disease Supplement 2004). The risk of venous thromboembolic disease in women taking hormone therapy is 2-fold. A meta-analysis of 4 trials (Heart and Estrogen/Progestin Replacement Study, Estrogen in Venous Thromboembolism Trial, Women's Estrogen for Stroke Trial and WHI) has shown relative risk of pulmonary embolism is increased (RR $2.16,95 \% \mathrm{CI}$ 1.47-3.18). The PHASE trial, as described above reported 2/134 thromboembolic events in the E2/NETA arm and 0/121 events in the placebo arm (Clark et al 2002).

\section{Stroke}

Stroke is the third leading cause of death in the US. Eight randomized controlled trials have evaluated the rate of stroke in postmenopausal women and most have shown an increased risk of stroke with hormone replacement therapy (ACOG Stroke Supplement 2004). The WHI trial reported an increased risk in stroke (OR $=1.44,95 \%$ CI 1.09, 1.90), however, different estrogen/progestin formulation was used. The PHASE trial, as previously described, reported 5/134 events of nonfatal stroke in the E2/NETA group and 3/121 events in placebo arm $(\mathrm{OR}=1.50)$ (Clark et al 2002). At this time, it is unlikely whether the increased risk of stroke depends on the specific hormone preparation. Women should be counseled prior to the initiation of hormone therapy about the increased risk of stroke. Hormone therapy should be discontinued in anyone experiencing a cerebrovascular event.

\section{Colorectal cancer}

Colorectal cancer accounts for $11 \%$ of all cancer related deaths, and the age specific incidence for women aged 50-54 years is 41.3 per 100,000 women (American Cancer Society 2003). To our knowledge, no investigators have

Table 5 Incidence of endometrial hyperplasia with unopposed estrogen or combination norethindrone acetate/estradiol therapy

\begin{tabular}{|c|c|c|c|c|}
\hline & E2 I mg & $\begin{array}{l}\text { E2 I mg/ } \\
\text { NETA } \\
0.5 \text { mg }\end{array}$ & $\begin{array}{l}\text { E2 I mg/ } \\
\text { NETA } \\
0.25 \text { mg }\end{array}$ & $\begin{array}{l}\text { E2 I mg/ } \\
\text { NETA } \\
0.1 \mathrm{mg}\end{array}$ \\
\hline $\begin{array}{l}\text { Patients undergoing } \\
\text { endometrial biopsy }\end{array}$ & 247 & 241 & 251 & 249 \\
\hline $\begin{array}{l}\text { Patients with } \\
\text { endometrial hyperplasia }\end{array}$ & $36(14.6 \%)$ & I (0.4\%)* & I (0.4\%)* & $2(0.8 \%)^{*}$ \\
\hline
\end{tabular}


Table 6 Incidence of endometrial hyperplasia after treatment of unopposed E2 vs E2/NETA after one year of therapy

\begin{tabular}{|c|c|c|c|c|}
\hline Medication & E2 $50 \mu \mathrm{g}$ & $\begin{array}{l}\text { E2 } 50 \mu \mathrm{g} / \\
\text { NETA I } 40 \mu \mathrm{g}\end{array}$ & $\begin{array}{l}\text { E2 } 50 \mu \mathrm{g} / \\
\text { NETA } 200 \mu \mathrm{g}\end{array}$ & $\begin{array}{l}\text { E2 } 50 \mu g / \\
\text { NETA } 400 \mu g\end{array}$ \\
\hline $\begin{array}{l}\text { Endometrial } \\
\text { hyperplasia }\end{array}$ & $37.9 \%$ & $0.8 \% *$ & $1 \% *$ & $\begin{array}{l}1.1 \% * \\
* p<0.01\end{array}$ \\
\hline
\end{tabular}

reported the relative risk of colon cancer among women taking the specifically E2/NETA. However, the results of the WHI and several meta-analyses have reported a significant reduction in the incidence of colorectal cancer in women taking combination hormone replacement therapy (RR 0.56, 95\% CI 0.38-0.81). Several hypotheses exist on the protective mechanism of estrogen, which include the bile acid hypothesis, the estrogen receptor- $\beta$ hypothesis and the gene-receptor hypothesis. Secondary bile acids are carcinogenic, and hormone therapy has shown to decrease bile acid synthesis (Grodstein et al 1999). Estrogen receptor- $\beta$ expression has been shown to decrease colon cancer cell growth in vitro (Fiorelli et al 1999). Finally, the estrogen receptor gene may inactivate other gene expression and has been shown to suppress the growth of cancer cells in vitro and in vivo (Al-Azzawi and Whaab 2002).

\section{Breast cancer}

The association between estrogen and breast cancer was established well over 100 years ago (Beaston 1896). Risk factors for breast cancer include increased exposure to estrogen, such as early menarche, late full-term pregnancy and late menopause. Breast tissue can concentrate, metabolize and produce estrogen. Estrogen plays a role in the expression and transcription of growth factors and oncogenes (Verheul et al 2000). Progesterone is a mitogen in human breast cells and this cell proliferation may be the underlying process by which DNA damage occurs (Pike et al 1993). Data from the WHI showed that women who take hormone therapy are more likely to develop breast cancer than women who do not (HR $1.24,95 \%$ CI 1.01-1.54) (Rossouw et al 2002). Women should be counseled that the risk of breast cancer is increased with hormone therapy and dissipates when it is discontinued. A randomized trial (Hormonal Replacement Therapy after Breast Cancer-is it Safe?) investigated the effect of hormone therapy for women who were previously treated for breast cancer. The trial was discontinued because of a significant increase in breast cancer events (HR 3.3, 95\% CI 1.5-7.4) (Holmberg et al 2004). Alternatives to hormone therapy should be offered for women with a history of breast cancer.

Table 1 summarizes the risks and benefits of combination hormone therapy.

\section{Side effects}

The most common side effects of E2/NETA are uterine bleeding, headache, abdominal pain, and breast pain. Postmenopausal bleeding is a common side effect of hormone therapy, and is the most important factor determining whether postmenopausal women continue hormone therapy is uterine bleeding. Studies comparing bleeding profiles of different hormone therapy regimens are mixed. Johnson et al randomized women to E2/NETA or CEE/MPA to compare bleeding patterns. After 6 months of therapy, amenorrhea was significantly higher in the E2/NETA group (54.8\%) than the CEE/MPA group (17.1\%) (Johnson et al 2002), which paralleled previous findings by Simon et al (2001). However, more recently Yildirim et al (2006) found no difference in bleeding patterns in women randomized to E2/NETA or CEE/MPA.

Rowan et al (2006) pooled 3 studies to determine the efficacy and tolerability of NA/EE and found that amenorrhea and adverse side effects were similar to placebo (Table 7).

Table 7 Side effects of E2/NETA based on three randomized controlled trials

\begin{tabular}{|c|c|c|c|c|c|c|}
\hline Study & \multicolumn{2}{|c|}{$\begin{array}{l}\text { Endometrial: hyperplasia } \\
\text { I } 2 \text { months duration }\end{array}$} & \multicolumn{2}{|c|}{$\begin{array}{l}\text { Vasomotor symptom } \\
\text { study: } 3 \text { months }\end{array}$} & \multicolumn{2}{|c|}{$\begin{array}{l}\text { Osteoporosis } \\
\text { study: } 24 \text { months }\end{array}$} \\
\hline Medication & \multicolumn{2}{|c|}{$1.0 \mathrm{mg}$ E2/0.5 mg NETA } & \multicolumn{2}{|c|}{1.0 mg E2/0.5 mg NETA } & \multicolumn{2}{|c|}{1.0 mg E2/0.5 mg NETA } \\
\hline Duration of medication & \multicolumn{2}{|l|}{12 months } & \multicolumn{2}{|l|}{3 months } & \multicolumn{2}{|l|}{24 months } \\
\hline Control group & \multicolumn{2}{|c|}{ Estradiol I mg } & \multicolumn{2}{|l|}{ Placebo } & \multicolumn{2}{|l|}{ Placebo } \\
\hline Side effect & E2/NETA & Estradiol & E2/NETA & Placebo & E2/NETA & Placebo \\
\hline Headache & $16 \%$ & $5 \%$ & $3 \%$ & $3 \%$ & $6 \%$ & $4 \%$ \\
\hline Gastroenteritis & $2 \%$ & $2 \%$ & $0 \%$ & $0 \%$ & $6 \%$ & $4 \%$ \\
\hline Nausea & $3 \%$ & $5 \%$ & $10 \%$ & $0 \%$ & $11 \%$ & $0 \%$ \\
\hline Breast pain & $24 \%$ & $10 \%$ & $21 \%$ & $0 \%$ & $17 \%$ & $8 \%$ \\
\hline
\end{tabular}


Table 8 Contraindications to combination estradiol/progestin therapy

Undiagnosed vaginal bleeding

Personal history of breast cancer

Known history of estrogen-dependent neoplasia

Active or history of deep venous thrombosis or pulmonary embolism

Active or history of arterial thrombotic event, including myocardial

infarction or cerebral vascular accident

Liver disease

Hypersensitivity to medication

Pregnancy

\section{Continuation rates and cost- effectiveness of E2/NETA}

Simon et al (2003) compared continuation rates among women using 6 different hormone replacement therapies and found that patients prescribed $1 \mathrm{mg}$ NETA/5 $\mu \mathrm{g}$ E2 were $52 \%$ more likely to continue therapy than patients prescribed $0.625 \mathrm{mg} \mathrm{CEE} / 2.5$ or $5 \mathrm{mg}$ MPA.

Coyle et al (2003) compared the cost effectiveness and quality of life of E2/NETA and CEE/MPA. Measures of quality of life included presence and absence of vaginal bleeding, menopausal symptoms and hip fracture along with lifetime costs for a 50-year-old menopausal woman on therapy for 5 years. This investigator concluded that E2/NETA is cost effective for women with menopausal symptoms (US\$900/ quality adjusted life-years (QALY) gained for EE/NETA vs US\$20,300/QALY gained for CEE/MPA).

\section{Contraindications to hormone therapy}

Table 8 lists contraindications to combination estradiol/ progestin therapy.

\section{Conclusion}

The goal of postmenopausal hormone therapy is to alleviate the symptoms that are associated with the loss of estrogen that women experience after menopause. Current indications for postmenopausal E2/NETA hormone therapy include treatment of severe vasomotor symptoms and prevention of postmenopausal osteoporosis; E2/NETA is likely equivalent to other hormonal preparations. Therapy should commence at the lowest effective dose and should be discontinued after the shortest duration possible. The choice of whether or not to begin therapy is ultimately the patient's choice but also requires physicians providing care to postmenopausal women to effectively discuss the risks and benefits of estrogen and/or progestin replacement therapy.

\section{References}

ACOG Coronary Heart Disease Supplement. 2004. Obstet Gynecol, 104:1S-48S

ACOG Stroke Supplement. 2004. Obstet Gynecol, 1044:97S-105S.

ACOG Venous Thromboembolic Disease. 2004. Obstet Gynecol, 104:118S-27S.

Adler G, Young D, Galant R, et al. 2005. A multicenter, open-label study to evaluate satisfaction and menopausal quality of life in women using transdermal estradiol/norethindrone acetate therapy for the management of menopausal signs and symptoms. Gynecol Obstet Invest, 59:212-19.

Al-Azzawi F, Whaab M. 2002. Estrogen and colon cancer:current issues. Climacteric, 5:3-14.

American Cancer Society. 2003. Cancer facts and figures. Atlanta, GA: ACS.

Archer DF, Furst K, Tipping D, et al. 1999. A randomized comparison of continuous combined transdermal delivery of estradiol-norethindrone acetate and estradiol alone for menopause. Obstet Gynecol, 94:498-503.

Arabi A, Garnero P, Porcher R et al. 2003. Changes in body composition during post-menopausal hormone therapy:a 2 year prospective study. Human Reprod, 18:1747-52.

Baerug U, Winge T, Nordland G, et al. 1998. Do combinations of $1 \mathrm{mg}$ estradiol and low doses of NETA effectively control menopausal symptoms? Climacteric, 1:219-28.

Beaston GT. 1896. On the treatment of inoperable cases of carcinoma of the mamma: suggestions for a new method of treatment with illustrative cases. Lancet, 2:104-7.

Brett KM, Reuben CA. 2003. Prevalence of estrogen or estrogen-progestin hormone therapy use. Obstet Gynecol, 102:1240-9.

Claudia Stahlberg C, Anette Tønnes Pedersen AT, Elsebeth Lynge E, et al. 2003. Hormone replacement therapy and risk of breast cancer: the role of progestins Acta Obstetricia et Gynecologica Scandinavica, 82:335-44.

Clark JH, Schrader WT, O'Malley BW. 1992. Mechanism of action of steroid hormones. Williams Textbook of Endocrinology. p 35-90.

Clark SC, Kelleher J, Lloyd-Jones H, et al. 2002. A study of hormone replacement therapy in postmenopausal women with ischaemic heart disease:the Papworth HRT atherosclerosis study. BJOG, 109:1056-62.

Christiansen C, Christensen MS, McNair P. 1980. Prevention of postmenopausal bone loss: controlled 2 year study in 315 normal females. Eur J Clin Invest, 280:822-6.

Christiansen C, Christensen MS, Transboel I. 1981. Bone mass in postmenopausal women after withdrawal of oestrogen/getsten replacement therapy. Lancet, 1:459-61.

Christiansen C, Riis B. 1990. 17ß-Estradiol and continuous norethisterone:a unique treatment for established osteoporosis in elderly women. J Clin Endocrinol Metab, 71:836-41.

Coyle D, Cranney A, Tugwell P. 2003. Economic evaluation of norethisterone acetate/ethinyl estradiol (FemHRT) for women with menopausal symptoms. Pharmacoeconomics, 21:661-9.

Executive Summary. 2004. Obstet Gynecol, 104(Suppl):1S-4S.

Fiorelli G, Picariello L, Martineti V, et al. 1999. Estrogen synthesis in human colon cancer epithelial cells. J Steroid Biochem Mol Biol, 71:223-30.

Fosbery WHS. 1897. Severe climacteric flushings successfully treated by ovarian extract. Br Med J, $i: 1039$.

Gambacciani M, Ciaponi M, Cappagli, et al. 2003. Effects of low-dose, continuous combined estradiol and norithsterone acetate on menopausal quality of life in early postmenopausal women. Maturitas, 44:157-63.

Grady D, Herrington D, Bittner V, et al. 2002. Cardiovascular disease outcomes during 6.8 years of hormone therapy:Heart and Estrogen/progestin Replacement Study follow-up (HERS II). JAMA, 288:49-57. 
Grodstein F, Newcomb PA, Stampfer MJ. 1999. Postmenopausal hormone therapy and the risk of colorectal cancer:a review and meta-analysis. Am J Med, 106:574-82.

Hing E, Brett KM. 2006. Changes in U.S. prescribing patterns of menopausal hormone therapy, 2001-3. Obstet Gynecol, 108:33-40.

Holmberg L, Anderson H, HABITS steering and data monitoring committees. 2004. HABITS, a randomized comparison:trial stopped. Lancet, 363:453-5.

Johnson JV, Davidson M, Archer D, et al. 2002. Postmenopausal uterine bleeding profiles with two forms of continuous combined hormone replacement therapy. Menopause, 9:3-5.

Kurman RJ, Felix JC, Archer DF, et al. 2000. Norethindrone acetate and estradiol-induced endometrial hyperplasia. Obstet Gynecol, 96:373-9.

Manson JE, Allison MA, Rossouw JE, et al. 2007. Estrogen therapy and coronary-artery calcification. $N$ Engl J Med, 356:2591-602.

McClung M. 1998. Efficacy of Activelle to increase bone mineral density in postmenopausal women. Bone, 23(Suppl).

Pike MC, Spicer DV, Dahmoush L, et al. 1993. Estrogens, progestogens, normal breast cell proliferation, and breast cancer risk. Epidemi Rev, 15:17-35.

Popp AW, Bodmer C, Senn C, et al. 2006. Prevention of postmenopausal bone loss with long-cycle hormone replacement therapy. Maturitas, 53:191-200.

Portman DJ, Symons JP, Wilborn W, et al. 2003. A randomized, doubleblind, placebo-controlled, multicenter study that assessed the endometrial effects of norethindrone acetate plus ethinyl estradiol versus ethinyl estradiol alone. Am J Obstet Gynecol, 188:334-42.

Ravn P, Bidstrup M, Wasnich RD, et al. 1999. Alendronate and estrogenprogestin in the long-term prevention of bone loss: four-year results from the Early Postmenopausal Intervention Cohort Study. Ann Intern Med, 131:935-42.

Rossouw JE, Anderson GL, Prentice RL, et al. 2002. Risks and benefits of estrogen plus progestin in healthy postmenopausal women:principal results from the Women's Health Initiative randomized controlled trial. JAMA, 288:321-33.

Roux C, Pelissier C, Fechtenbaum, et al. 2002. Randomized, double-masked, 2-year comparison of tibolone with 17 beta-estradiol and norethindrone acetate in preventing postmenopausal bone loss. Osteoporos Int, 13:241-8.
Rowan JP, Simon JA, Speroff L, et al. 2006. Effects of low-dose norethindrone acetate plus ethinyl estradiol $(0.5 \mathrm{mg} / 2.5 \mu \mathrm{g})$ in women with postmenopausal symptoms:Updated analysis of three randomized controlled trials. Clin Ther, 28:921-32.

Simon SA, Symons JP, femhrt Study Investigators. 2001. Unscheduled bleeding during initiation of continuous combined hormone replacement therapy:a direct comparison of two combinations of norethindrone acetate and ethinyl estradiol to medroxyprogesterone acetate and conjugated equine estrogens. Menopause, 8:321-7.

Simon JA, Wysocki S, Brandman J, et al. 2003. A comparison of therapy continuation rates of different hormone replacement agents:a 9-month retrospective, longitudinal analysis of pharmacy claims among new users. Menopause, 10:37-44.

Smith YR, Love T, Persad CC, et al. 2006. Impact of combined estradiol and norethindrone therapy on visuo-spatial working memory assessed by functional magnetic resonance imaging. J Clin Endocrinol Metab, 91:4476-81.

Speroff L, Fritz MA. 2005. Clinical Gynecologic Endocrinology and Infertility. Baltimore: Lippincott, Williams and Wilkins.

Stahlberg C, Pederson AT, Lynge E, et al. 2003. Hormone replacement therapy and risk of breast cancer:the role of progestins. Acta Obstet Gynecol Scand, 82:335-44.

Verheul HA, Coelingh-Bennink HJ, Kenemans P, et al. 2000. Effects of estrogens and hormone replacement therapy on breast cancer risk and on efficacy of breast cancer therapies. Maturitas, 36:1-17.

Weiderpass E, Adami HO, Baron JA, et al. 1999. Use of oral contraceptives and endometrial cancer risk (Sweden). Cancer Causes Control, 10:277-84.

Wells M, Sturdee DW, Barlow DH, et al. 2002. Effect on endometrium of long term treatment with continuous combined oestrogen-progestogen replacement therapy: follow up study. BMJ, 325:1-5.

Yildirim G, Tugrul S, Uslu H, et al. 2006. Effects of two different regimens of continuous hormone replacement therapy on endometrial histopathology and postmenopausal uterine bleeding. Arch Gynecol Obstet, 273:268-73. 